\title{
Does Tanzanian participatory forest management policy achieve its
} governance objectives?

Magessa, Kajenje; Wynne-Jones, Sophie; Hockley, Neal

\section{Forest Policy and Economics}

DOI:

https://doi.org/10.1016/j.forpol.2019.102077

Published: 01/02/2020

Peer reviewed version

Cyswllt i'r cyhoeddiad / Link to publication

Dyfyniad o'r fersiwn a gyhoeddwyd / Citation for published version (APA):

Magessa, K., Wynne-Jones, S., \& Hockley, N. (2020). Does Tanzanian participatory forest management policy achieve its governance objectives? Forest Policy and Economics, 111(February 2020), [102077]. https://doi.org/10.1016/j.forpol.2019.102077

\footnotetext{
Hawliau Cyffredinol / General rights

Copyright and moral rights for the publications made accessible in the public portal are retained by the authors and/or other copyright owners and it is a condition of accessing publications that users recognise and abide by the legal requirements associated with these rights.

- Users may download and print one copy of any publication from the public portal for the purpose of private study or research.

- You may not further distribute the material or use it for any profit-making activity or commercial gain

- You may freely distribute the URL identifying the publication in the public portal ?
}

Take down policy

If you believe that this document breaches copyright please contact us providing details, and we will remove access to the work immediately and investigate your claim. 
Does Tanzanian Participatory Forest Management Policy Achieve Its Governance Objectives?

Kajenje Magessa $^{* a, b}$, Sophie Wynne-Jones ${ }^{\text {a }}$, Neal Hockley ${ }^{a}$

* Corresponding author: College of Environmental Science and Engineering, Bangor University, Deiniol Road, Bangor, Gwynedd, LL57 2UW, Wales. United Kingdom. Email: kajenjes@yahoo.com; afp654@bangor.ac.uk

a College of Environmental Science and Engineering, Bangor University, Deiniol Road, Bangor, Gwynedd, LL57 2UW, Wales. United Kingdom

b Tanzania Forestry Research Institute, P.O Box 1854, Morogoro, Tanzania 


\begin{abstract}
Before the 1980s, centralized forest policies in many African countries excluded local communities, while forest resources were frequently degraded. In response, Participatory Forest Management (PFM) was introduced to devolve management and improve livelihoods, forest condition and governance. Building on existing analyses that highlight the limited successes of PFM, this study focuses on the equitability and efficacy of PFM governance in Tanzania. Previous work notes several shortcomings of PFM, often stressing the issue of elite capture - our paper explores this issue in further detail by applying a mixed methods approach. Specifically, by using individual rather than household level surveys we can better assess the extent of marginalisation and whether wealth and gender are determining factors. We assess whether PFM has achieved devolution by comparing observed outcomes to stated policy objectives and the decentralization framework developed by Agrawal and Ribot (1999). We surveyed 227 individuals, in two case study villages adjacent to SULEDO Village Land Forest Reserve (Kiteto District), conducted six focus group discussions and 10 key informant interviews to answer these research questions: (a) To what extent are management institutions representative and inclusive of the local community? (b) To what extent are local communities empowered to influence decision-making and access benefits? (c) To what extent is the local forest management institution accountable to local communities relative to superior authorities under PFM? In the case study villages, PFM is characterised by a low rate of resident and Village Environmental Committee member engagement in committee elections, formal village assemblies, PFM training, formulation and first-approval of by-laws. Low levels of satisfaction were also found with the mechanisms of benefit sharing and the level of accountability of management institution leaders. We found that SULEDO has become dominated by a very restricted "elite within an elite", comprising only zonal leaders and close associates. Overall, we found a significant gap between observed outcomes and PFM policy objectives, and therefore a failure to fully achieve meaningful devolution.
\end{abstract}

Keywords: Participatory Forest Management policy; governance objectives; devolution 


\section{Introduction}

Before the 1980s centralized forest policies in many countries excluded local communities, while often failing to prevent degradation of forest resources (Haller et al., 2008). In the early 1980s, inclusion of local communities in forest management increased through the adoption of 'Participatory Forest Management' (PFM) in many countries (Tole, 2010). PFM was promoted with the intention of improving livelihoods, forest condition and governance, but studies to date have documented mixed ecological and livelihood impacts (e.g. Persha and Blomley, 2009; Schreckenberg and Luttrell, 2009; Bowler et al., 2012; Lambrick et al., 2014; Lund et al., 2018).

Reviewing a range of international cases, Dressler et al., (2010) found that implementation of PFM excluded marginalised groups from access, use, and control of valued forest resources, suggesting serious shortcomings in social justice terms. Ribot et al., (2010) similarly contend that in a majority of cases across sub-Saharan Africa, local PFM institution members are not representative of the local population. Reporting of inequalities is common across several studies, with local elites seen to dominate both decision-making and benefit-capture (Coulibaly-Lingani et al., 2011; Lund and Saito-Jensen, 2013; Adhikari, 2014; Green and Lund, 2015; Luintel et al., 2017; Etongo et al., 2018; Das, 2019). Jacob and Brockington (2017) further explain this in a Tanzanian context, with reference to the lack of accountability and transparency of the local institutions, enabling favouritism and manipulation to occur by politically powerful and well connected individuals.

Other analyses detail how PFM is characterised by partially elected community representatives (Chinangwa et al., 2016; García-López, 2019), with a lack of capacity (Mohammed et al., 2017), transparency in handling funds, and accountability to their constituents (Mollick et al., 2018; Coleman and Fleischman, 2012). High costs of forest resources (e.g. timber) are also seen to exclude the poorest from benefiting from PFM (Kumar, 2002; Rai et al., 2017). This situation has increased intra-and inter-community conflicts (Gross-Camp et al., 2019). In other instances, PFM policies and central government transferred limited powers to local communities (Chomba et al., 2015; Das, 2019), and devolved power is contested between districts and villages (Sungusia and Lund 2016). Active involvement of foresters in PFM may also reduce the sense of ownership and power that local communities may exercise (Scheba and Mustalahti, 2015). Overall, the efficacy and equitability of PFM governance frameworks are central to the failings described (e.g. Chomba et al., 2015; Chinangwa et al., 2016; Jacob and Brockington, 2017; Maraseni et al., 2019; Mollick et al., 2018; Das, 2019; García-López, 2019; Kabir et al., 2019). 
A key point here is the need to explicitly compare outcomes to stated policy objectives, which whilst evident in some studies (Chomba et al., 2015; Mollick et al., 2018; Das, 2019), is not always the case. This has prompted critique from Lund et al. (2018), who question the level of policy understanding shown in some evaluations. In addition to direct policy comparison (Chomba et al., 2015; Mollick et al., 2018; Das, 2019), best-practice frameworks have been used to guide a number of existing analyses. Here, Agrawal and Ribot's 1999 framework is particularly notable in its guidelines for democratically elected and downwardly accountable local actors, and equitable benefit sharing (see e.g. Chomba et al., 2015; Chinangwa et al., 2016; Mutune and Lund 2016; Das, 2019).

To assess the efficacy of PFM implementation, existing studies draw on a range of data, derived from both qualitative and quantitative assessment to provide both the richness and breadth of insight required. A notable weakness of previous studies that we aim to address here is the focus of surveys at the household level. Both household and individual surveys aim to generalise the findings to a wider population, however household surveys may lead to an unrepresentative sample, particularly in terms of gender as household heads (and thus the respondents addressed) are normally men. In order to assess whether PFM has achieved devolution, we need studies that ensure all the different socio-economic characteristics of a heterogeneous community are considered, which may influence respondents' engagement with, and knowledge and perceptions of PFM. This study aims to achieve this by employing an individual-level survey to residents and VEC members, where respondents (residents) were selected using proportionate stratified random sampling based on gender and wealth status. The aim was to examine whether knowledge and perceptions of PFM differed strongly between residents and to explore whether there was evidence of elite capture in PFM. The survey measured the extent of all devolution components (i.e. representativeness, empowerment and accountability of actors). A quantitative survey also enables us comprehensively determine the extent to which villagers have been involved in the PFM processes. Qualitative data were also collected from surveys, focus group discussion and key informant interviews to explicitly address the perspectives of potentially marginalised groups. The combination of qualitative and quantitative data is critical here to both capturing and understanding the issues at hand. Qualitative reporting adds more analytical depth, to more fully explain how and why elite capture has occurred, whilst the quantitative gives us a more rigorous means of understanding who that elite are. Our analysis compares observed outcomes to stated policy objectives and the decentralization framework developed by Agrawal and Ribot (1999). The research addressed the following questions; (a) To what extent are management institutions representative and inclusive of the local community? (b) To what extent are local communities 
empowered to influence decision-making and access benefits? (c) To what extent is the local forest management institution accountable to local communities relative to superior authorities under PFM? Across all the research questions we were also interested to understand how individual characteristics such as gender and wealth affect people's satisfaction and participation empowered by PFM. We conducted our study in Tanzania because it is among the top three countries in Africa that had made most progress in terms of numbers of communities involved and hectares of forest involved in PFM, hence many countries borrowed Tanzania PFM experience (e.g Uganda, Kenya, Ghana, Nigeria, Madagascar, Malawi, Mozambique, Guinea, Namibia) (Alden -Wily, 2001). We purposively selected the case study from a wider stratified random sample of PFM communities in Tanzania because of its history of donor support. It might therefore be expected to represent a "best-case" scenario of PFM in Tanzania, relatively well-resourced compared to many other PFM projects

\section{Analytical framework}

We assess whether PFM in Tanzania has achieved devolution, by comparing observed outcomes to stated policy objectives; and actors, empowerment and accountability elements in the decentralization framework developed by Agrawal and Ribot (1999). The underlying contention of the framework is that the PFM approach should be assessed by looking at which actors are involved, the degree of meaningful powers transferred to local actors, and how those actors are downwardly and upwardly accountable to constituents and government respectively. This is further detailed below.

\section{Representativeness}

Meaningful devolution requires that members of the relevant institutions are elected by, and representative of, all community members, with special consideration of marginalised groups, and indeed representativeness and accountability are inextricably linked (Agrawal and Ribot 1999). PFM in Tanzania is intended to achieve this (URT, 1998. PS 3.p.27; URT, 2002, s.33.p.52 and s.38.p.59; URT, 2007, p.5). Mogoi et al. (2012) found that there was at least some level of resident participation in elections, however, they document that PFM principles are not well implemented in practice. 


\section{Empowerment}

Empowerment refers to (1) capacity to manage resources; (2) authority to make decisions and rules, and then approve and implement these rules; (3) the degree to which communities adjacent to forests can decide about the use and access of forest resources (Agrawal and Ribot 1999). PFM aims to achieve devolution by: promoting awareness of forest rules; enabling access to forest benefits for all members of the community; and fully transferring utilization rights, management, decision-making and enforcement powers to elected local representatives (Agrawal and Ribot 1999; URT, 2002.s.16.p. 17. S.33.p.35; URT, 2007. p.21). Moreover, devolving powers to make decisions and rules without devolving powers to enforce them, limits devolution (Agrawal and Ribot 1999). Several studies have documented that communities and local institutions in PFM lack awareness of forest rules and their enforcements (Chhetri et al., 2012; Senganimalunje et al., 2015). Some studies (e.g. Lund and Treue, 2008), report more positive findings, where local actors feel empowered by enhanced knowledge of forest rules, and consequently dare to challenge their leaders when PFM policy and legislation has been contravened. Other scholars reported that local institutions lack capacity to address power struggles (Mogoi et al., 2012), and conflicts (Senganimalunje et al., 2015) which arise due to a lack of inclusiveness, and elite capture in decision making processes Saito-Jensen et al., 2010 ; Chhetri et al., 2013; Mutune et al., 2017; Liu et al., 2018). PFM has created a new arena for power struggles between different interest groups (Kellert et al., 2000; Mustalahti and Lund 2009; Mogoi et al., 2012), and thus implementation of PFM policy and legislation at a local level can be more dominated by coercion than cooperation (Ribot et al., 2010; Schusser et al., 2015). In addition, many PFM programmes fail to achieve access to forest benefits for all community members (Kellert et al., 2000 ; Chhetri et al., 2012; Mogoi et al., 2012; Nielsen and Meilby, 2013), and the tightened control of forest resource utilization in PFM is frequently most costly to the poorest and marginalised groups (Ribot, 2004; Chhetri et al., 2012; Kumar et al., 2015) and characterised by marginalization of minorities (Persson and Prowse, 2017; Rai et al., 2017). PFM has also been found to weaken the level of support that the central government could provide to local institutions (Gobeze et al., 2009; Mustalahti and Lund 2009; Persha and Blomley 2009; Mohammed and Inoue 2012; Ameha et al., 2014; Dyer et al., 2014; Bekele et al., 2015). Specifically, Mustalahti and Lund (2009) argue that benefitssharing arrangements prior to PFM were more effective in motivating central government to support local communities.

\section{Accountability}

PFM is expected to improve forest governance if democratically elected bodies are both downwardly and upwardly accountable (Agrawal and Ribot, 1999; Larson, 2002; Ribot 2004; 
URT, 2002, s. 33.p.35; URT, 2007.p. 21). This may help to counteract local elite capture (Lund and Saito-Jensen, 2013; Agrawal and Ribot 1999). In order to understand the nature of accountability, it is necessary to make a detailed assessment of how and to whom actors are accountable (Agrawal and Ribot 1999). The most commonly cited mechanisms used to enforce accountability are electoral processes; third party monitoring; auditing and evaluations; public reporting and existence of sanctions that are enforced (Ackerman, 2004). Furthermore, transparency and accountability in handling of revenues and expenditures is also important for accountability (Zulu, 2008). However, most studies demonstrate that PFM is characterised by a lack of downward and upward accountability (e.g. Mustalahti and Lund 2009; Mohammed and Inoue 2012; Persson and Prowse 2017) and distrust of local institutions by local communities (Nielsen and Meilby, 2013)

\section{Methods}

\section{Study area}

In Tanzania, PFM was introduced in the early 1990s, following this a number of policies and legislation were reviewed to grant legal rights for villages to own and manage forest resources that are on village land (URT, 1998;URT, 2002). In 2006, it was estimated that 3,672,854 hectares were under some form of PFM (URT, 2006). The area under PFM continued to increase so that in 2012 PFM covered 7,758,788 hectares (URT, 2012).

The study was undertaken in the Kiteto district and the fieldwork was conducted from February - September 2017. Ethnic composition in the district includes Maasai (32\%), Gogo (27\%), Rangi (18\%) and a mixture of smaller groups (23\%) e.g. Kamba, Nguu, Bena, Kaguru, Hehe, Sandawi, Burunge, and Wa-Arusha (Lissu and Mitzlaff, 2007). The main land uses include grazing, agriculture, settlements, forest conservation, beekeeping, timber harvesting, charcoal making, firewood and honey gathering while the largest land use category is grazing (LAMP, 2005). Traditionally, the Maasai and Kamba are pastoralists and all the remaining ethnic groups are agriculturalists. However, this division has become less clear-cut due to land scarcity and modern lifestyles, which have restricted movements of the pastoralists (Lissu and von Mitzlaff 2007).

The district has one Village Land Forest Reserve (VLFR) called SULEDO. SULEDO was established in the mid-1990s with great facilitation from LAMP, who also played a significant role in formulating SULEDO rules (Pers Com, ZEC leader). Since its establishment, SULEDO 
has been supported by donors until 2012 ${ }^{1}$. In 2002 SULEDO VLFR received international recognition and was awarded the inaugural UNDP Equator Prize (UNDP, 2012). Currently the forest is managed by 13 villages under Community Based Forest Management (CBFM), a form of PFM where the forest is owned by democratically elected Village Governments who are the users and managers of forest resources (Alden Wily, 1997). In 2007, the forest was officially gazetted as VLFR (ORGUT, 2010). SULEDO covers $1674.16 \mathrm{~km}^{2}, 10 \%$ of the district area. The forest is located at about $126 \mathrm{~km}$ South East from Kiteto district headquarters. SULEDO VLFR is rich in miombo woodlands and dominated by Combretum molle and Dalbergia melanoxylon, Julbernadia globiflora and Brachystegia microphylla (Malimbwi, 2000).SULEDO was purposively selected for this study from the class of PFM most common in Tanzania: miombo woodlands, managed for conservation and production, restricted to those that had received donor support. We selected SULEDO because it is a flagship case, having received donor support for a long time. The rationale for selecting a site that had received support is that it would be expected to represent a "best-case scenario" for PFM in Tanzania, and therefore a useful test of how far PFM has succeeded in achieving devolution and policy objectives under the most promising circumstances.

\section{Sampling design}

Two villages and four sub villages were selected using stratified random sampling (see Appendices A, B and C). Lists of all adults (aged 18 or over) in each sub village were obtained from key informants, and stratified according to gender and then wealth status using wealth indicators developed with input from key informants, including size of land owned, number of livestock owned, income sources, roof and wall materials for house owned (see Appendices I and J), which are also commonly used in the literature (Vyamana, 2009; Hargreaves et al., 2007). Residents ${ }^{2}(\mathrm{n}=180)$ were selected using stratified random sampling in each sub-village in order to ensure that the sample in each stratum was in proportion to the stratum in the population (Table 1). All 47 Village Environmental Committee (VEC) members were purposively selected. A total of 227 respondents (residents and VEC members) undertook our questionnaire survey. In cases where selected residents were absent or unwilling to participate in the study, the next resident on the list was selected for an interview. A total of 6 selected respondents were unavailable and 1 declined to undertake the survey. VEC members are residents in a leadership position, and their responsibility is to coordinate PFM activities at

\footnotetext{
${ }^{1}$ Source: Regional and district natural resources officers and Chairperson of Zonal Environmental Committee in the study area.

${ }^{2}$ Residents comprise adult individuals who are resident in an area, and excludes those with positions on the Village Environmental Committee who were selected separately.
} 
local level. VEC members may be expected to have greater knowledge of PFM than residents. Residents consisted of individuals in the community without any leadership position in PFM. 
Table 1: Number of respondents interviewed in each study village.

\begin{tabular}{|c|c|c|c|c|c|c|c|c|c|}
\hline \multirow[t]{2}{*}{ Village name } & \multicolumn{3}{|c|}{ Adult population } & \multicolumn{3}{|c|}{ Residents interviewed } & \multicolumn{3}{|c|}{ Committee members interviewed } \\
\hline & Total & Male & Female & Total & Male & Female & Total & Male & Female \\
\hline Sunya & 2607 & 1370 & 1237 & 146 & 68 & 78 & 33 & 21 & 12 \\
\hline Engang'ungare & 616 & 275 & 341 & 34 & 14 & 20 & 14 & 10 & 4 \\
\hline Total & $3223(100 \%)$ & $1645(51 \%)$ & $1578(49 \%)$ & $180(100 \%)$ & $82(46 \%)$ & $98(54 \%)$ & 47 & $31(66 \%)$ & $16(34 \%)$ \\
\hline
\end{tabular}




\section{Quantitative methods}

Quantitative data were collected using a questionnaire survey with open and closed questions to investigate knowledge of the programme, participation in PFM activities, and perceptions of the legitimacy, trust and accountability of the committee (see Appendix D). The questionnaires for the study were first developed in English and then translated into Swahili and Maasai. Quantitative data were analysed using R version 3.4.4 (R Core Team, 2018), Chi-square tests were employed to test for differences in perceptions and opinion between residents and VEC members, since VEC members may be expected to be more aware and engaged with PFM than residents. A logistic regression model was used to analyse the relationship between individuals' characteristics and their participation in PFM activities. The ordinal regression model was performed to gain insight into how individual characteristics were associated with the level of satisfaction with the mechanism of sharing benefits in PFM. The best supported models were selected using the Akaike Information Criterion (AICc).

\section{Qualitative methods}

Qualitative methods were also employed acknowledging that survey data cannot capture all the complexities of social relations in the area. Key informant interviews were undertaken with 10 key informants at community level. This included village leaders, VEC leaders, the Zonal Environmental Committee (ZEC) chairperson, and village government chairpersons, who were in position during establishment of the SULEDO VLFR. Key informant interviews aimed to gain a richer perspective and triangulate information derived from the questionnaire survey (see Appendix E). Focus group discussions were used as a way of gaining collective sense on how PFM is implemented and gain accounts that are more naturalistic than those collected in questionnaire surveys (Mitchell and Branigan, 2000). Focus group discussions were undertaken with marginalised groups (women and the poorest) and members of VEC separately in each of the study villages after the questionnaire survey (6 focus group discussions with 38 individuals per focus group). Focus group discussions involved relatively unstructured questions, but the discussion was guided to focus on issues raised by the questionnaire survey and key informant interviews (see Appendix F). Some qualitative data was also obtained from the individual surveys through open ended response questions, which allowed respondents to provide fuller explanations if they wished. All interviews and focus group discussions were audio recorded and transcribed, Nvivo 10 software was employed to support thematic analysis. Overall, for the different data assessed, we compared observed outcomes to stated policy objectives and the decentralization framework developed by Agrawal and Ribot (1999) based 
on the three elements of devolution (i.e. representativeness, empowerment and accountability of actors). 


\section{Results}

\section{Representativeness of actors in the SULEDO PFM programme}

Tanzania's policies require PFM to be managed by village level committees elected by all village members through a village assembly (the meeting of all adult members held at least four times a year), (URT, 1982,s.55.p.32), and to be representative of all parts of the community, with special consideration of marginalised groups (URT, 1998. PS 3.p.27; URT, 2002, s.33.p.52 and s.38.p59; URT, 2007, p.5 and 12). This is in line with Agrawal and Ribot's (1999) decentralization framework. However, we found in practice, implementation of PFM may diverge from the PFM policy. In the SULEDO VLFR, management of the forest is under three levels of Environmental Committees. The overall management is under the ZEC. ZEC leaders (Chairperson, Secretary and Treasurer) are elected by ZEC members through the ZEC assembly, with 2/3 of all ZEC members. The ZEC chairperson must be elected from among ZEC members, while the ZEC secretary may be elected from outside of the ZEC members (URT, 2011, s.3.p.14). The ZEC is formed by the chairperson, secretary and treasurer of each VEC, elected by VEC members (at least one of these three VEC leaders must be female) which is in turn composed of two members of different genders from each Sub-village ${ }^{3}$ Environmental Committee (SEC), who are elected by the village assembly. The SEC is nominated by sub-village assembly and approved by the village assembly. (SULEDO management and harvesting plan, URT, 2011, s.3.p 7 and 10). This is in line with PFM policy (see Figure 1). The village government is responsible for enforcing election rules at village level and the ZEC chairperson is accountable to village governments and is responsible for enforcing election rules at zonal level (URT, 2011, s.3.p 14 and 15).

However, awareness of who manages SULEDO VLFR was low: 19\% of VEC members and 38\% of other residents were not aware of the committee(s) responsible for managing SULEDO VLFR (Figure 2a). Awareness of how the VEC assumed their positions and when the last committee election took place, was also low among both VEC members and other residents. Half of the residents expressed ignorance as to how VEC members assume their position and even $15 \%$ of VEC members did not know how they became a member of the committee. $2 \%$ of VEC members reported that they were appointed by village government leaders, $2 \%$ that they were appointed by sub village chairpersons, while another $2 \%$ reported that they were appointed by forest guides (Figure 2b).

\footnotetext{
${ }^{3}$ A "Sub-village" is a recognised sub-part of a registered village (UTR, 2007, p. 5).
} 


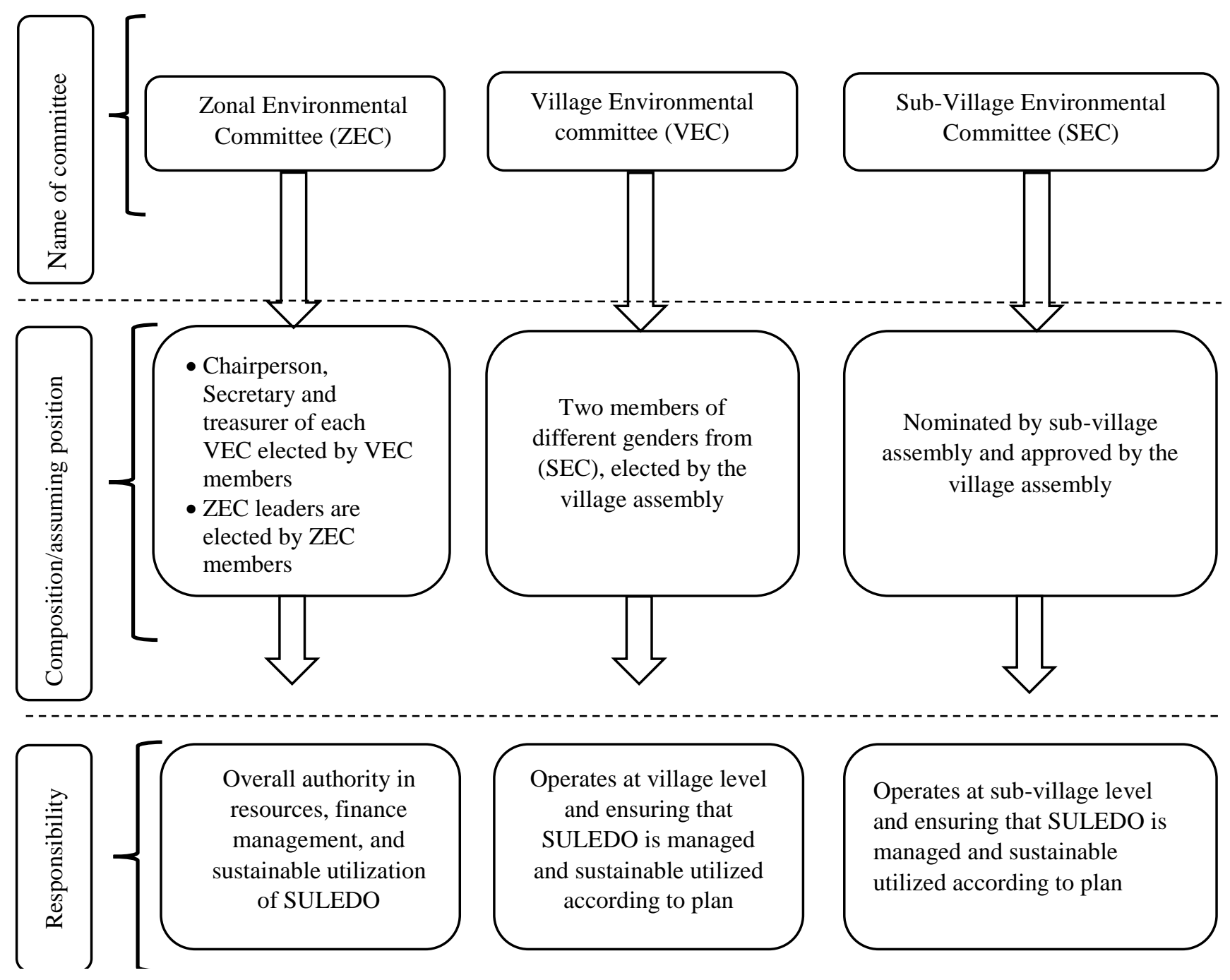

Figure 1: Committee composition, their responsibility and how they should assume their position, according to PFM policy (URT, 2002; URT, 2007; URT 2011).

Only $27 \%$ of residents and $21 \%$ of VEC members stated correctly that members of the VEC are elected through the village assembly. $44 \%$ of residents and $22 \%$ of VEC members did not know when the last committee election was. $15 \%$ of residents and $24 \%$ of VEC members stated correctly that the committee election was conducted in 2017 , while $20 \%$ of residents and $24 \%$ of VEC members stated that the last election was conducted in 2016. Perhaps more importantly, only $18 \%$ of residents and $60 \%$ of committee members participated in the last election (Figure 3). 


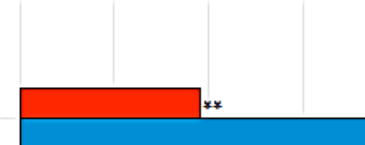

Zonal Environmental Committe

Village Environmental Committee

Village Government

All Village

Village and Zonal Environmental Committee

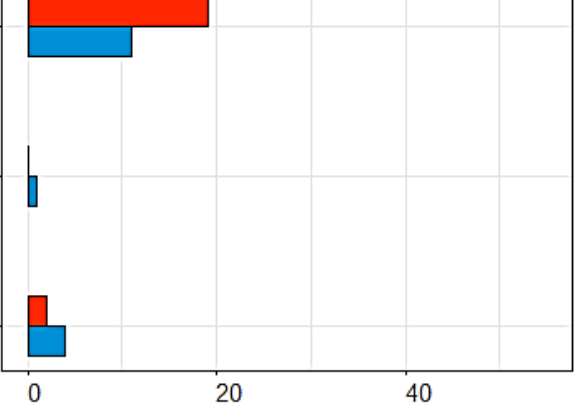

Percentage of respondents (b)

Nominated by villagers and confirmed by village government council

Elected by Zonal Environmental Committe

Elected by villagers through ward assembly

Elected by villagers through sub village assemb

Elected by villagers through village assemb

Elected by Village Environmental Committee-

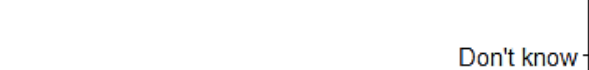

Don't know-

Appointed by Zonal Environmental Committee Leaders

Appointed by village government leaders

Appointed by village government counci

Appointed by sub village chairperson

Appointed by Forest Guide Chairperson

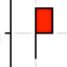

$\square$

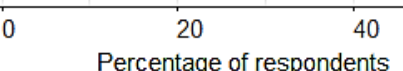

$\square$ Residents $\square$ Village Environmental Committee

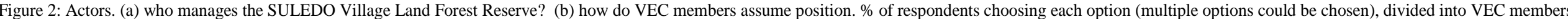
and other residents. Chi -square test was used to compare VEC members' and other residents' perceptions, at $1 \%(* * *)$ and $5 \%(* *)$ level of significance. 


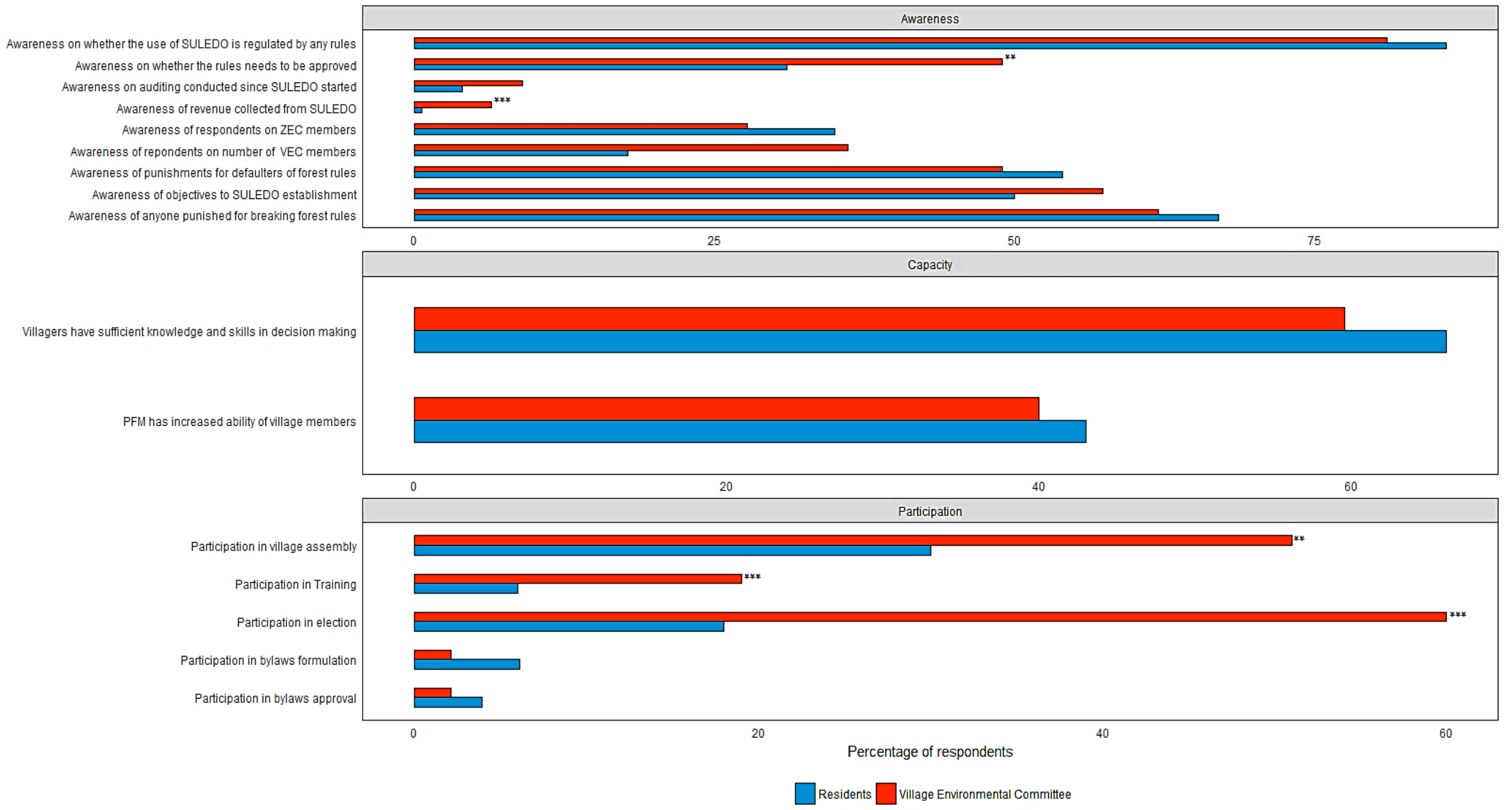

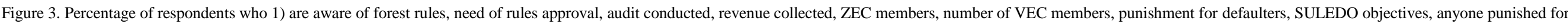

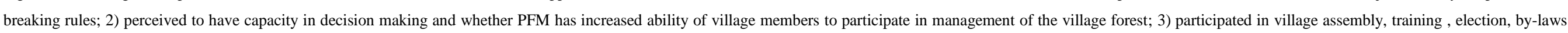
formulation and approval; (only one option could be chosen). Note: chi -square test was used to compare VEC members' and other residents' perceptions, at $1 \%(* * *)$ and $5 \%$ (**) level of significance. 


\section{Empowerment of residents and local institutions in the SULEDO PFM programme}

In a PFM programme all community members are expected to have access to resources, participate in capacity building, decision making, formulation of by-laws and first approval of by-laws. For example, Tanzanian PFM policies require committee members to be trained in forest management skills with an understanding that these committee members will then train their constituents (URT, 1998.PS.3 and 5; URT, 2002.s.16.p. 17. s.33.p.35; URT, 2007. p.21).

Participation in village assemblies and training was low among both groups, but was higher among VEC members ( $49 \%$ and $19 \%$ respectively) than other residents ( $31 \%$ and $6 \%$ respectively, $\mathrm{p}=0.02$ and $p=0.003$, Figure 3 ). Those who did participate in trainings were not necessarily involved in making decisions over management and utilization of SULEDO VLFR.

"ZEC leaders organise committee elections in order to show the government that they're managing SULEDO accordingly. But in practice we are not involved in any PFM activities and there are some individuals who are not committee members but have personal ties with ZEC leaders who are actively involved. For example, when PFM training comes for VEC members, ZEC leaders tend to assign non VEC members to undertake the training with the agreement of sharing the allowance given during training. For example, if they're paid 15000 TZS (6.52 dollars) per day then the participant will take 10000 TZS (4.35 dollars) and ZEC leader will be given 5000 TZS (2.17dollars)” (FGD 1, VEC members).

Nonetheless, a majority of residents and VEC members felt they had the knowledge and skills to participate in decision making (Figure 3). The ZEC chairperson is responsible for ensuring that all decisions made by the ZEC are communicated to residents through the VEC and the village government concerned (URT, 2011, s.3.p10). The VEC is responsible for ensuring that SULEDO VLFR is used according to the management and sustainable harvesting plans and should inform residents through village governments about all decisions made regarding the forest, by the ZEC (URT, 2011, s.3.p 7 and 8). However, only a few VEC members were actively involved in training, village assembly, by-laws formulation and approval, suggesting an elite within the elite (i.e. the ZEC leaders) and hence raising concerns about who has control. Focus Group Discussions with women and VEC members as well as key informant interviews with Village chairperson and Executive Officer revealed that decisions in SULEDO VLFR are made only by ZEC leaders.

"We are aware that all decisions in SULEDO VLFR are supposed to be made through the village assembly but we know nothing about what is going on in SULEDO VLFR. All the decision are made by VEC and ZEC and we have never been invited to attend any decision making village assembly or participate in any PFM activities. The forest is continuing to be harvested but we are not benefiting with the funds obtained from harvests" (FGD 2, women). 
Village chairperson noted as follows.

"We are not informed and involved in any decision making with regard to management and utilization of SULEDO VLFR, because the decisions are made by only the committee [ZEC] and village government leaders and the forest is continuing to be harvested without the consent of either the VEC or residents" (FGD 1).

The Village leader stated emphatically the following:

"As a village leader I'm responsible for ensuring that all regulations and rules are well implemented but according to PFM policies I'm not part of ZEC meeting and I have not been informed about any decision made by the ZEC' (KI3, Village Executive Officer).

One of the village chairpersons summed up the situation as follows:

"The ZEC is supposed to inform residents about any decision made about SULEDO VLFR for approval, however, currently not all decisions made by ZEC are taken to either residents or the village government office. Likewise as a village leader I'm currently not invited to ZEC meetings that concern decision making over harvesting of the forest" (KI2, Village chairperson).

Overall, access to forest resources did not differ significantly between residents and VEC members $(\mathrm{p}=0.359$, Figure 4a). However, residents were more likely to access firewood, building materials and medicinal plants than VEC members ( $p<0.001$, Figure 4a). Although the results show access to forest resources is high for both residents and VEC members, their access was mainly to low value forest resources. The access to timber was low and did not differ significantly between residents and VEC members: only $22 \%$ of residents and $11 \%$ of VEC members accessed timber $(\mathrm{p}=0.08$, Figure 4a). Further evidence provided in interviews, survey and focus groups enhances our insights here, suggesting that a restricted elite (that excludes both ordinary residents and VEC members) may be dominating access to higher value timber resource harvesting; working against the PFM objective of equitable benefit sharing.

"No permit is provided to residents to access timber from SULEDO VLFR and those who manage to access timber bought the timber from ZEC but also had person ties to ZEC leaders. You can have money but you won't be able to access timber" (FGD 1, VEC members).

One respondent in the individual survey put it this way:

"I can afford to buy timber from SULEDO but it has been difficult to get timber for roofing my house, due to excessively complicated informal procedures that ZEC leaders brought. For example, recently I saw ZEC leaders were supervising harvest in the forest, then I went to ZEC office to ask if they were selling timber because I wanted timber for my house but I was answered 
that there is no timber. This situation forced me to buy the timber in Kilindi district" (Individual survey, Respondent 208).

"We are not benefitting from the funds and timber obtained from SULEDO VLFR, only ZEC and village leaders are the ones benefiting. We think it's not possible for village leaders to remain silent if they were not benefiting with funds obtained from SULEDO VLFR" (FGD3, poorest individuals). 

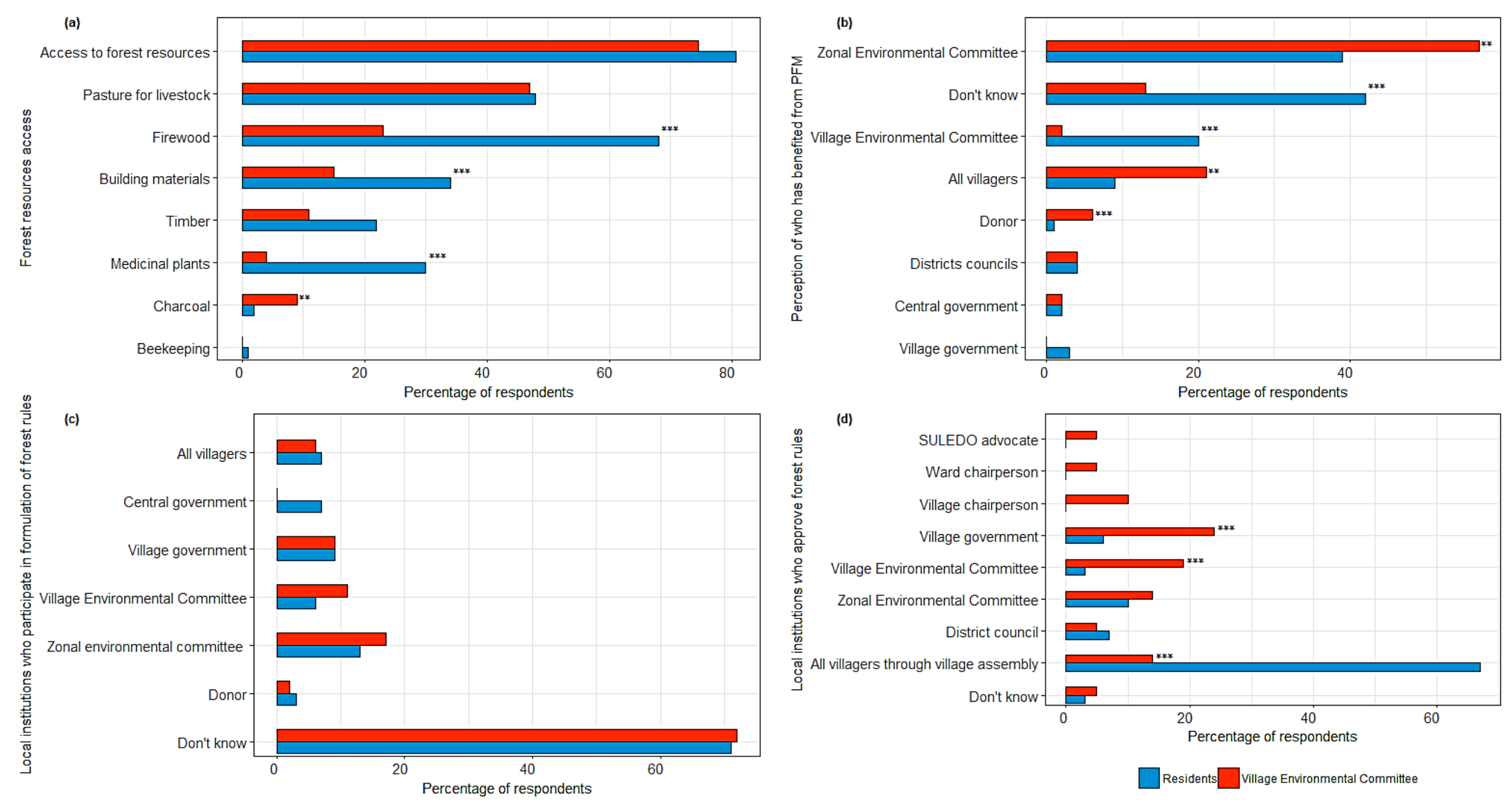

$\square$ Residents $\square$ Village Environmental Committee

Figure 4: Empowerment; (a) Forest resources accessed from SULEDO VLFR; b) who has benefited from SULEDO VLFR

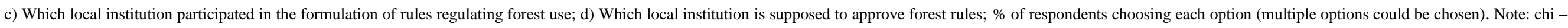
square test was used to compare residents and VEC responses, at $1 \%(* * *)$ and $5 \%(* *)$ level of significance 
The SULEDO VLFR plan specifies that all villagers should benefit from the programme (URT 2011, s.2.p5). Residents (20\%) were more likely to state that the VEC had benefitted than the VEC members $(2 \%)(\mathrm{p}=0.003$, Figure $4 \mathrm{~b})$ while $42 \%$ did not know who benefitted. VEC members $(57 \%)$ were more likely to state that the ZEC had benefitted than residents $(39 \%, \mathrm{p}=0.022)$, and only $9 \%$ of residents and $21 \%$ of VEC members felt that all villagers had benefitted. (Figure $4 \mathrm{~b}$ ). Furthermore, VEC members were more likely to report that donors had benefitted from the SULEDO VLFR than residents ( $\mathrm{p}=0.007$, Figure $4 \mathrm{~b}$ ). The SULEDO VLFR plan specifies clearly that profits obtained from SULEDO VLFR should be distributed equally amongst the villages that own the forest (URT, 2011, s.6.p16). However, satisfaction with the mechanism of benefits sharing is low amongst both residents and VEC members, as well as amongst both male and female residents (Figure 5). Interviews with village and VEC chairpersons and a focus group with VEC members revealed that they felt that revenue from SULEDO VLFR benefits only ZEC leaders. In addition VEC leaders are members of ZEC but they were not actively involved in all PFM activities with regards to the utilization and management of SULEDO. VEC members claimed that ZEC leaders and the VEC chairperson are the ones benefitting most.

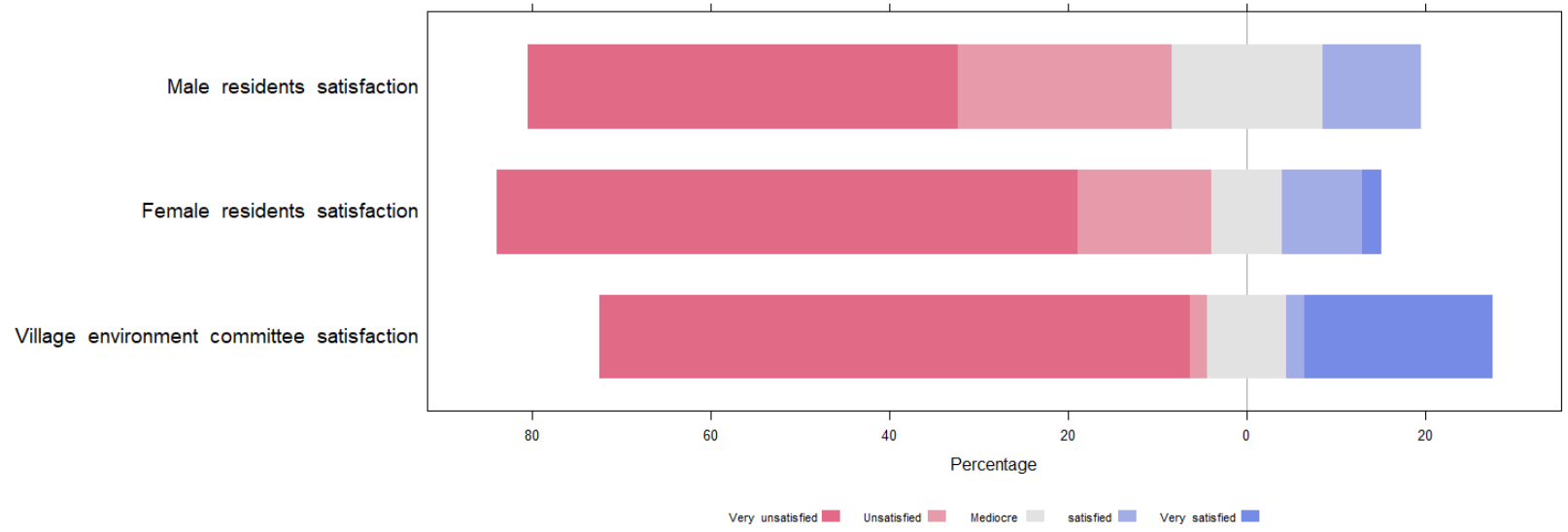

Figure 5: Percentage of residents and VEC members expressing different levels of satisfaction with the mechanism of sharing benefits.

"We are now approaching three years without receiving any share of benefits from SULEDO VLFR though the forest is continuing to be harvested" (KI2, Village chairperson).

The leader of a VEC reported the situation as follows:

“As a VEC leader and ZEC member I'm supposed to report all decisions about SULEDO to villagers through village government leaders but this is not happening. No decisions made by ZEC leaders are taken to other ZEC members. Currently villagers are not benefiting from revenue obtained from SULEDO. The last time for villages to receive a share of revenue from the forest was in 2004, where by each village received 1,000,000 TZS (USD 434). Since 2004, it is about 13 years though timber harvest is going on, but ZEC leaders are not reporting to other ZEC members, VEC, village leaders and residents, the revenue and expenditure from SULEDO. 
I'm not informed, even villagers are not informed, on how SULEDO vehicle and tractor were obtained" (K4, VEC leader).

ZEC leaders benefit more from SULEDO, because they normally made SULEDO decisions without involving and informing other ZEC members, VEC members, village government or residents. We are not informed on how the revenue from the forest has been spent, since ZEC leaders are not reporting revenue or expenditure to VEC, village government and residents. In addition, VEC chairperson is also benefiting with SULEDO, since it is impossible for ZEC leaders to start harvesting timber without communicating with VEC chairperson of the village concerned (FGD1, VEC members).

Rules and regulations that support the management plan (fines, sanctions) must be formulated and first approved by villagers through the village assembly (Forest Act: s. 34 (4); KI3). A majority of residents $(71 \%)$ and VEC members (72\%) expressed ignorance as to who formulated the rules (Figure 3c). Only $7 \%$ of residents and $6 \%$ of VEC members stated that the rules were formulated by all villagers (Figure 4c). In practice, an interview with the ZEC leader revealed that villagers were not involved in formulating the forest rules, all forest rules were substantially formulated by the donor in the first place.

"The rules regulating forest use were formulated by the donor (LAMP) and first approved by ZEC" (KI1, ZEC leader).

Moreover, participation in by-law formulation was low for both residents (6\%) and VEC members (2\%) (Figure 2).

As might be expected, VEC members (49\%) were more likely to be aware of the need for rules to be approved than residents $(31 \%)(\mathrm{p}=0.018$, Figure 3$)$, however, awareness was quite low in both groups. Perceptions of who should approve rules differed significantly between residents and VEC members. Residents are more likely to believe (correctly) that rules should be approved by all villagers ( $\mathrm{p}=0.005$, Figure $4 \mathrm{~d}$ ), while VEC members were more likely to believe that rules should be approved by the village government $(\mathrm{p}=0.008$, Figure $4 \mathrm{~d})$. Participation in by-laws approval was very low for both residents (4\%) and VEC members (2\%) (Figure3).

Although respondents have relatively good awareness that the use of SULEDO is regulated by rules, they lack awareness of how these rules operate. $54 \%$ of residents and only $49 \%$ of VEC members were aware that SULEDO VLFR has sanctions that are enforced for breaking the programme rules. These punishments include penalty fees, imprisonment, and confiscation of tools. Both residents and VEC members were lacking precise information (according to PFM policy) of the sanctions for rule breaking. $67 \%$ of residents and $62 \%$ of committee members were 
aware that individuals who fail to comply with the rules and regulations for the programme have been punished (Figure 3).

Logistic regression models were used to predict participation in village assemblies and in elections based on individual characteristics (see Appendix G for model-averaged coefficients). Even the best supported models (as measured by AICc) had low explanatory power (adjusted r-squared $20 \%$ and $16 \%$ respectively). However, there is some evidence that being older and male increases the likelihood of participating in a village assembly, while committee members were more likely to participate in elections. In addition, an ordinal regression model was used to predict the level of satisfaction with the mechanism of sharing benefits based on individual characteristics (see Appendix K for model-averaged coefficients), but even the best supported model (by AICc) had very low explanatory power (adjusted r-squared 6\%).

\section{Actors' accountability in the SULEDO PFM programme}

The VEC in Engang'ungare village has a total of 16 members and in Sunya 36 members. However, awareness of their identity, and that of current ZEC members, was low amongst both residents and VEC members (Figure 3).

"We as members of the committee, we do not know each other, this discussion you're conducting with us is our first time to be called to discuss about SULEDO VLFR" (FGD1).

The SULEDO VLFR plan requires leaders of the VEC to be elected through the VEC assembly, by a minimum of more than half of all the members (URT, 2011, s.3.p7). During focus group discussions with VEC members, it was noted that most VEC members did not participate in such elections:

“We didn't vote for chairperson, secretary and treasurer because we were not informed" (FGD1). VEC members are supposed to stay in position for five years until the next election (URT, 2011, s.3.p7: KI1). $71 \%$ of residents and $43 \%$ of VEC members expressed ignorance of the terms for VEC members. Furthermore, some of the village government leaders lacked awareness of the terms for VEC members. 

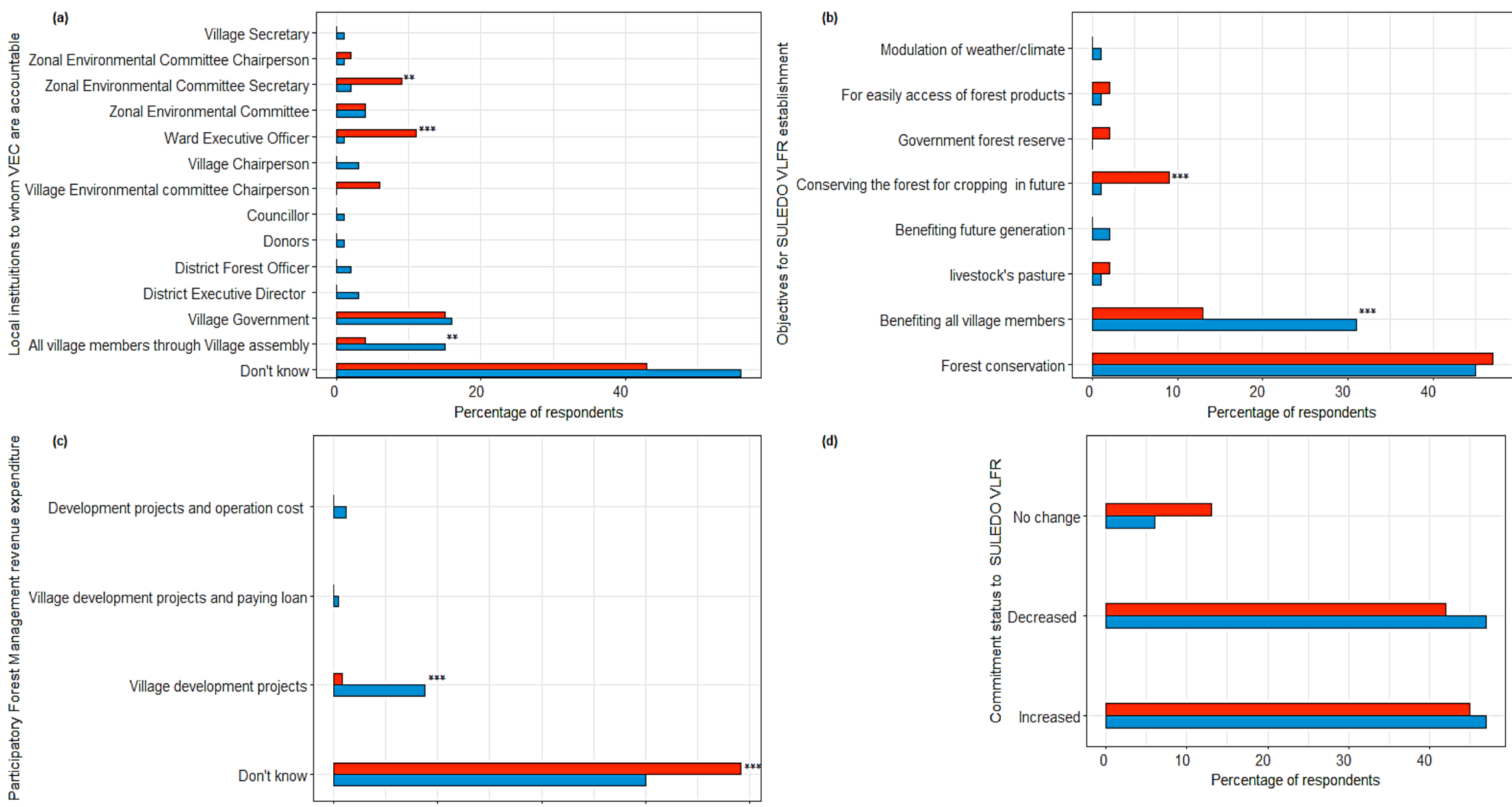

Percentage of respondents

(d)

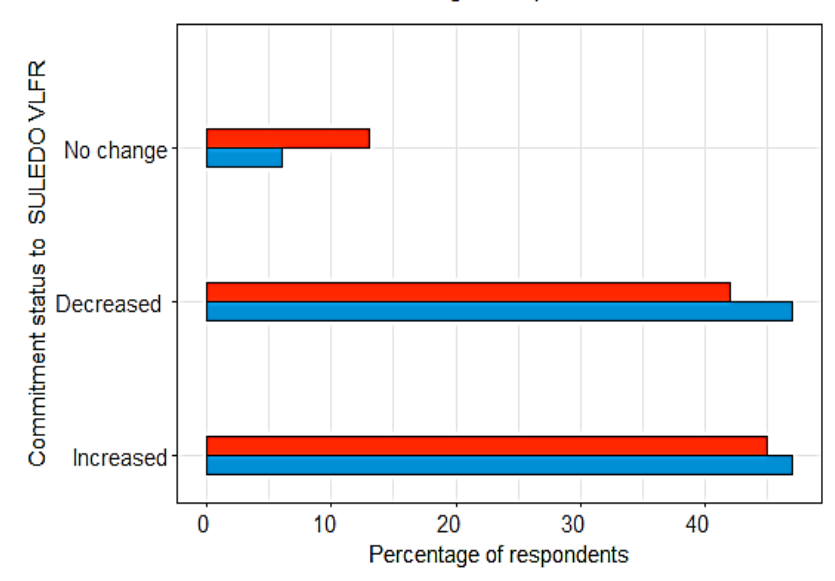

$\square$ Residents $\square$ Village Environmental Committee

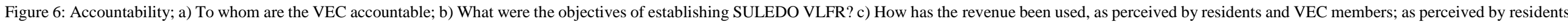

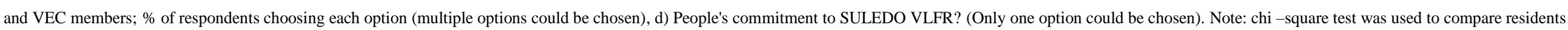
and VEC perception, at 1\% (***) and 5\% (**) level of significance 
PFM policies require the VEC to be accountable to the village government and village assembly (URT, 2002, s. 33.p.35; URT, 2007.p. 21). SULEDO VLFR plan specifies that the VEC must report monthly, quarterly and annually to the village government on management, revenue, permits, compensation, harvest and expenditure (URT, 2011, s.4 and 6.p12 and 16). The village government must then report this information to residents (URT, 2011, s.4 and 6.p13 and 16). However, there was low awareness amongst both residents and VEC members as to whom VEC members were accountable (see Figure 6a), with qualitative data affirming that VEC accountability is lacking.

"Since I was elected to be in this position [Village leader], I have never received any reports from either the ZEC or VEC on management and the revenue accrued from the forest and I have no power to question them". (KI2).

Moreover, only $1 \%$ of residents and $6 \%$ of VEC members were aware of how much revenue has been collected so far from SULEDO VLFR. The amount of revenue mentioned included 880, 1,320, 13,200 US Dollars, much lower than the 23,760 US Dollar reported by key informants from ZEC. Withdrawal of funds from the SULEDO account must be approved by residents through village assemblies. Likewise the revenue from SULEDO should be spent according to a revenue and expenditure budget prepared by ZEC and approved by residents through village assembly (URT, 2011, s.6.p16). However, 75\% of residents and 98\% of VEC members did not know how the revenue from the forest has been used (Figure 6c). In an interview, the ZEC leader stated that revenue from SULEDO has been spent on village development projects, operational costs for the ZEC office and $10 \%$ of the revenue was shared with the district council. Only $3 \%$ of residents and no VEC members reported spending in this way. Residents (22\%) were more likely to state that revenue from the forest has been spent on village development projects than VEC members ( $2 \%$, $\mathrm{p}=0.004$ ) (Figure 6c). A forest official at district level noted that SULEDO was supposed to share $20 \%$ of the forest revenue with the district council but this had never happened in practice.

The ZEC is also required to employ an auditor from the private sector to check the SULEDO VLFR accounts once a year (URT, 2011, s.6.p16), but this does not appear to be happening.

Audits were conducted twice per year when the donors were supporting the programme, however no audits have been conducted since donor left 2012" (KI1)

The majority of residents stated that they did not trust the VEC, and that the VEC was very poor, or poor, in decision making and not accountable to, or legitimate representatives of, the village members (Figure 7). 


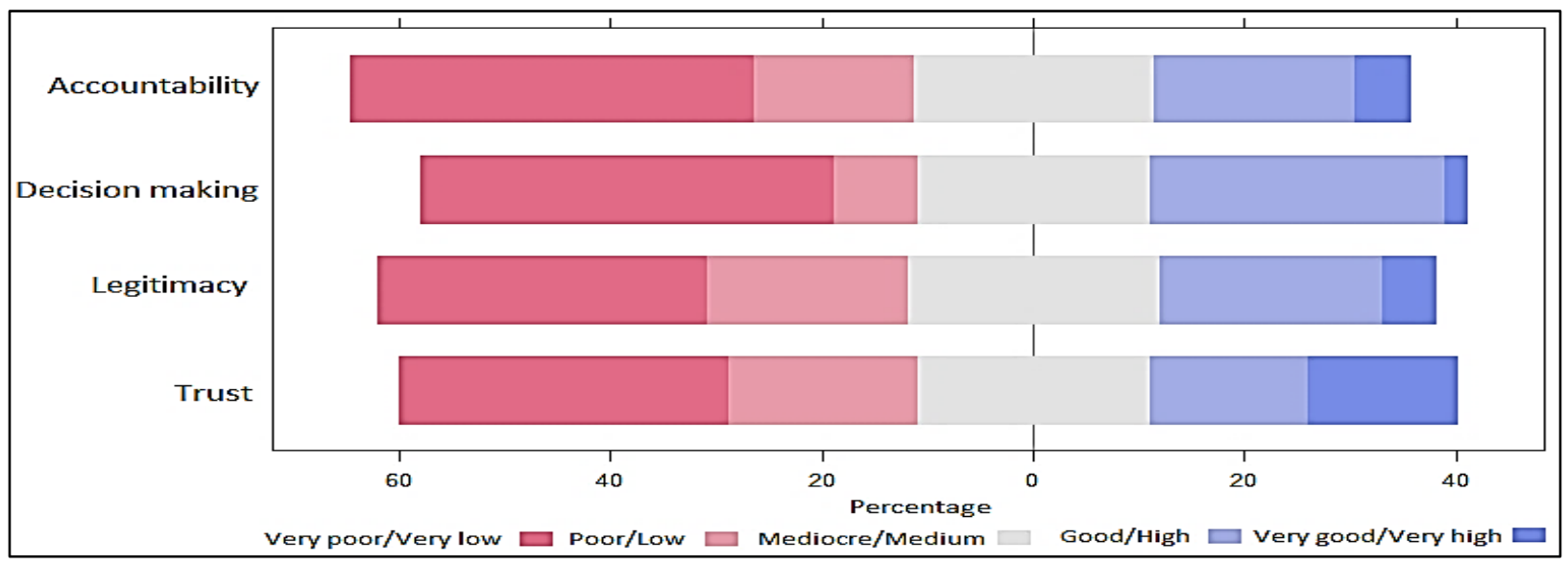

Figure 7: Residents' perception of levels of VEC accountability, decision making, legitimacy and trust.

The SULEDO VLFR management plan is particularly designed to ensure the forest benefits all residents and safeguards sustainable harvesting of forest products (URT, 2011, s.2.p5). Awareness of these objectives was low amongst both residents and VEC members (Figure 3). However, residents were more likely to be aware that the forest reserve is intended to benefit all villagers $(p=0.012$, Figure 6b). Finally, the self-reported ability of village members to participate in PFM was low (Figure 3). $47 \%$ of residents and $42 \%$ of VEC members felt that their commitment to SULEDO VLFR has decreased since the start of the forest (Figure 6d).

\section{Discussion}

PFM in Tanzania has established new local institutions that manage the forest on behalf of the villagers. However, villagers are not fully engaged in, or indeed aware of, the election of members for these institutions. VEC members are more likely to participate in voting for VEC members than other residents are, but even within the VEC participation remains low. In addition, much power is concentrated at a relatively high level with the ZEC leaders. Given the large area and population covered by SULEDO, approximately 54,000 people (UNDP, 2012), it may be that the ZEC leaders cannot adequately represent, or be representative of, the diversity of the communities concerned. As a result, there appears to be an elite within the elite, in terms of who has control of, and participates in, PFM decisions and activities. This contradicts aspirations for representativeness in the devolution of power through PFM (Agrawal and Ribot, 1999).

As well as being representative, institutions should be capable and empower local people (Agrawal and Ribot 1999). There are limited PFM training opportunities in SULEDO and the few trainings seem to be allocated only to individuals with a personal tie to ZEC leaders (e.g. relatives). Thus only a few residents and VEC members have participated in PFM training, limiting awareness of their rights, responsibilities and the power that they may exercise when leaders contravene the PFM policy, this may constrain effective PFM implementation. Coulibaly-Lingani et al. (2011) 
and Mogoi et al. (2012) in their studies in Burkina Faso and Kenya respectively, similarly report that villagers lack knowledge and capacities to effectively implement PFM.

Our results showed that participation in village assemblies was low; residents and VEC members who attended village assemblies were not necessarily involved in decision making over management and utilization of the forest. In practice, management activities and decision making involve only ZEC leaders, this limits the capacity of VEC members to know each other. This could prevent residents' preferences from being adequately addressed and suggests dominance in the programme by a small elite or clique (see also Bardhan, 2002; Persha and Andersson, 2014; Liu et al., 2018). For PFM to be effective, decisions need to accommodate the views and opinions of all residents with special consideration of marginalised groups (Agrawal and Ribot 1999). VEC members reported that only ZEC leaders were involved in key decision-making, while residents and village government leaders have no power to question them. Other studies have similarly suggested that decision making processes in PFM are not inclusive and may be dominated and controlled by a local elite (Ribot et al., 2010; Dressler et al., 2015; Liu et al., 2018), and now we have a wider base of responses from residents and committee members to substantiate this.

We have also outlined exclusion and failings with regards to the approval and understanding of rules and regulations. Although the community are aware of the existence of rules, regulations and sanctions for the programme, they lack awareness of how these rules operate and are not participating in the formulation and approval of by-laws at the outset. This limits the sense of ownership among residents and hence undermines effective implementation and enforcement of PFM rules and regulations. We also found a lack of transparency in how sanctions are enforced. This may lead committee leaders to bypass the forest management plan and manage the forest according to their own interest. Our findings are in line with Persson and Powse (2017), who found local communities implementing PFM in Cambodia lacked awareness of forest rules, and hence formal forest rules and regulation do not correspond to the 'rules' actually in use. Likewise, Liu and Innes (2015), found that local communities in China continue to implement the PFM approach with top-down decision making despite the need for bottom up approach and hence constrain effective PFM implementation.

Our results show that both residents and VEC members are dissatisfied with the mechanism of sharing benefits and few of them access timber. Interestingly we found no evidence that gender or wealth was associated with levels of satisfaction with benefit sharing mechanisms (see Liu et al., 2018). Although access to forest resources was not influenced by wealth status or gender, it did depend on the decision of committee leaders who tend to redistribute benefits in favour of individuals who are closer to and voted for them (see also Olken, 2007). For individuals and 
villages that are not well connected, it could be harder to secure programme benefits (Kamoto et al., 2013). This has decreased the commitment of some residents and VEC members to PFM.

Similarly, we had expected that participation in PFM activities and access to forest resources could be influenced by both wealth and gender status (e.g. Agrawal, 2001) and tested for this in our analyses. We found some evidence for an effect of gender and age, but not wealth per se. Moreover, our findings showed that participation in PFM activities were low amongst both residents and VEC members. This is consistent with our qualitative evidence that SULEDO has become dominated by a very restricted "elite within an elite" comprising only the ZEC leaders and close associates, rather than a broader group of VEC members or wealthier or male residents. This small elite has captured both decision-making processes and tangible benefits (e.g. training opportunities and timber harvesting).

Interviews revealed that some VEC members were appointed, rather than elected, limiting their accountability as they may be more likely to represent the interests of those who appoint them than their constituents (see e.g. Chinangwa et al., 2016; Liu et al., 2018). The length of term for committee members, audits and handling of finances are equally crucial elements in enhancing accountability of those who control the management of the resources (Agrawal and Ribot 1999). Although the management plan requires ZEC leaders to be downward accountable, our findings show that ZEC leaders are not reporting revenue and expenditure to VEC members, village government leaders or the village assembly, limiting downward accountability. When local institutions are not accountable to their constituents, devolution is not achieved, and elite capture is likely (Baruah, 2017). Our findings suggest that access to information is critical to ensure effective participation and reduce elite capture (Pasgaard and Chea, 2013; Persson and Powse 2017). Lack of transparency on revenue and expenditure limits the power that local communities may exercise (Reinikka and Svensson, 2004). Ignorance of length of term for VEC members and lack of audits also compromises the VEC's downward accountability. 


\section{Conclusions}

We have assessed the extent to which Tanzanian PFM policy achieves its governance objectives in a case study that has been relatively well-supported. We found that implementation of PFM fails to achieve at least some of the stated policy objectives for democratically elected, downwardly accountable local actors and equitable benefit sharing. Participation of residents in electing members of the VEC is low. The engagements of residents and VEC members in all PFM activities is low and a small elite seems to dominate the implementation of PFM at the zonal level, capturing both decision-making and benefits, to the dissatisfaction of other residents. Accountability of ZEC leaders to the VEC, village leaders, and residents is not evident. We found no evidence of successful resistance by marginalised groups operating through PFM institutions (though it may occur by other means, such as non-compliance, Lund and Saito-Jensen, 2013). We found little evidence for gender or wealth being a major factor determining participation amongst ordinary residents, but that appears to be because most ordinary residents, and even VEC members, seem relatively marginalised. This dominance by a small group aligned to the ZEC leaders has probably been facilitated by a low level of knowledge and engagement by ordinary residents and village level leaders. This may be because greater participation would require investment of significant time and effort, whereas the benefits of better governance would accrue to all residents. Overall, and despite SULEDO having received considerable donor support, it does not seem immune to the problems reported in other PFM projects elsewhere (Carter and Gronow 2005; Baruah, 2017; García-López, 2019; Gross-Camp et al., 2019). It is important to note, however, that we have compared the real-world performance of PFM against ideals of devolution and policy objectives. Our results should not be used to infer that PFM has not empowered local people relative to the situation prior to PFM. Relatedly, our findings represent a snapshot of the success of the PFM process around 22 years after it commenced in SULEDO, and five years after external support was phased out. Power relations are likely to evolve over time, and it may be that the dissatisfaction we observed will lead to elite dominance being challenged (Lund and SaitoJensen, 2013). By using standardised surveys with a representative sample of local residents, our study provides a baseline against which such developments might be measured.

In terms of practical recommendations, greater inclusion of villagers in elections might be achieved by improving awareness with regard to election calendars for committee members (Behera and Engel, 2006; Persson and Prowse, 2017). Government, external facilitators and committee leaders could explore effective and cost-efficient options for information exchange. Awareness raising and training beyond village assemblies, which targets all residents and offers opportunities amongst villagers for co-learning, might help to enhance capacity to implement PFM and awareness of rules. Finally, decision making processes should ensure effective inclusion of 
all parts of the community to avoid elites controlling decisions and capturing committees to which power is devolved. Ensuring inclusion of all villagers in by-law formulation and approval should enhance the sense of ownership and hence the enforcement of decisions (Agrawal and Ribot, 1999; Kamoto, 2007). Thus, external facilitators should allow enough time for wider consultations with all participants and assume advisory and facilitation roles during by-law formulation rather than owning the process. In order to ensure downward accountability and transparency in implementing the approach, there should be public audit and hearing sessions. All this would require ongoing support by donors and ultimately by state institutions. Although PFM was promoted partly as a devolved response to perceived state weakness, its success may still depend on the capacity of state institutions.

Caution is also required in assuming that better external support would be sufficient to address the weaknesses in PFM. SULEDO VLFR received donor support from the mid-1990s until at least 2012, yet failings are still apparent. Therefore, simply increasing support to local communities implementing the PFM might not be enough to achieve devolution if the policies themselves are not well designed, for example if the institutions imposed by PFM are too complex, or if the spatial scale over which PFM institutions operate is too large (larger than pre-existing village level institutions). Complexity and distance between decision-makers and those affected increases the barriers to participation, and dilutes the reward. PFM has created new institutions, which lie outside the existing democratic institutions of village government, and operate at higher spatial scale (in the case of the ZEC). Village government leaders appear to be relatively powerless to hold PFM leaders accountable in practice. Without idealising village government, it may be that the creation of entirely new structures has created opportunities for elite capture that might have been mitigated if existing structures, which might be better understood by residents, had been given greater power in the PFM process. 


\section{Acknowledgements}

We thank the Commonwealth Scholarships Commission for funding the study, Edwin Marco Igenge for assisting in data collection and local communities adjacent to SULEDO VLFR for their participation in the study. We also acknowledge two anonymous reviewers for comments and suggestions that allowed us to greatly improve the quality of our paper. 


\section{References}

Ackerman, J., 2004. Co-governance for accountability: beyond "exit" and "voice." World Dev. $32,447-463$.

Adhikari, S., Kingi, T., Genesh, S., 2014. Incentives for community participation in the governance and management of common property resources: the case of community forest management in Nepal.For.Policy Econ. 44, 1-9.

Agrawal, A., 2001. Common property institutions and sustainable governance of resources. World Dev. 29, 1649-1672.

Agrawal, A., Ribot, J.C., 1999. Accountability in Decentralization:A Framework with South Asian and African Cases. J. Dev. Areas 33, 473-502.

Alden Wily, L., 1997. Villagers as Forest Managers and Governments "Learning to Let Go" The case of Duru-Haitemba and Mgori Forests in Tanzania Forest Participation Series No. 9, International Institute for Environment and Development (IIED), London.

Alden -Wily, L., 2001. Facilitation Towards Community Based Forest Management of Minyughe Forest, Singida Rural District. Tanzania.

Ameha, A., Nielsen, O.J., Larsen, H.O., 2014. Impacts of access and benefit sharing on livelihoods and forest: Case of participatory forest management in Ethiopia. Ecol. Econ. 97, 162-171. https://doi.org/10.1016/j.ecolecon.2013.11.011

Bardhan, P., 2002. Decentralization of Governance and Development. J. Econ. Perspect. 16, $185-205$.

Baruah, M., 2017. Facipulation and Elite Formation Community Resource Management in Southwestern Ghana. Conserv. Soc. 15, 371-383.

Behera, B., Engel, S., 2006. Institutional analysis of evolution of joint forest management in India: A new institutional economics approach. For. Policy Econ. 8, 350-362. https://doi.org/10.1016/j.forpol.2005.08.006

Bekele, T., Ango, T.G., 2015. Do Interventions from Participatory Action Research Improve Livelihood and Reduce Conflicts Over Forest Resources? A Case Study from South Central Ethiopia. Small-scale For. 14, 441-458. https://doi.org/10.1007/s11842-015-9297-7 
Bowler, D.E., Buyung-Ali, L.M., Healey, J.R., Jones, J.P.G., Knight, T.M., Pullin, A.S., 2012. Does community forest Management provide global environmental benefits and improve local welfare? Front. Ecol. Environ. https://doi.org/10.1890/110040

Carter, J., Gronow, J., 2005. Recent Experience in Collaborative Forest Management. CIFOR Occassional Paper No. 43. Indonesia: Center for Internation Forestry Research. 57.

Chhetri, B.B.K., Hakon Johnsen, F., Konoshima, M., Yoshimoto, A., 2013. Community forestry in the hills of Nepal: Determinants of user participation in forest management. For. Policy Econ. 30, 6-13. https://doi.org/10.1016/j.forpol.2013.01.010

Chhetri, B.B.K., Larsen, H.O., Smith-Hall, C., 2012. Law Enforcement in Community Forestry: Consequences for the Poor. Small-scale For. 11, 435-452. https://doi.org/10.1007/s11842011-9194-7

Chinangwa, L., Sinclair, F., Pullin, A.S., Hockley, N., 2016. Can co-management of government forest reserves achieve devolution? Evidence from Malawi. For. Trees Livelihoods 25, 4158. https://doi.org/10.1080/14728028.2015.1087886

Chomba, S.W., Nathan, I., Minang, P.A., Sinclair, F., 2015. Illusions of empowerment? Questioning policy and practice of community forestry in Kenya. Ecol. Soc. 20. https://doi.org/10.5751/ES-07741-200302

Coleman, E.A., Fleischman, F.D., 2012. Comparing forest decentralization and local institutional change in Bolivia, Kenya, Mexico, and Uganda. World Dev. 40, 836-849. https://doi.org/10.1016/j.worlddev.2011.09.008

Coulibaly-Lingani, P., Savadogo, P., Tigabu, M., Oden, P. C., 2011. Decentralization and Community Forest Management in Burkina Faso: Constraints and Challenges. Int. For. Rev. 13, 476-486. https://doi.org/10.1505/146554811798811399

Das, B.K., 2019. Denial of Rights Continues: How Legislation for "Democratic Decentralisation" of Forest Governance was Subverted in the Implementation Process of the Forest Rights Act in India. Eur. J. Dev. Res. https://doi.org/10.1057/s41287-019-0195-2

Dressler, W., Büscher, B., Schoon, M., Brockington, D., Hayes, T., Kull, C.A., McCarthy, J., Shrestha, K., 2010. From hope to crisis and back again? A critical history of the global CBNRM narrative. Environ. Conserv. https://doi.org/10.1017/S0376892910000044

Dressler, W.H., McDermott, M.H., Schusser, C., 2015. The politics of community forestry in a Global Age - A critical analysis. For. Policy Econ. 58, 1-4. https://doi.org/10.1016/j.forpol.2015.04.006 
Dyer, J., Stringer, L.C., Dougill, A.J., Leventon, J., Nshimbi, M., Chama, F., Kafwifwi, A., Muledi, J.I., Kaumbu, J.-M.K., Falcao, M., Muhorro, S., Munyemba, F., Kalaba, G.M., Syampungani, S., 2014. Assessing participatory practices in community-based natural resource management: Experiences in community engagement from southern Africa. J. Environ. Manage. 137, 137-145. https://doi.org/10.1016/j.jenvman.2013.11.057

Etongo, D., Kanninen, M., Epule, T.E., Fobissie, K., 2018. Assessing the effectiveness of joint forest management in Southern Burkina Faso: A SWOT-AHP analysis. For. Policy Econ. 90, 31-38. https://doi.org/10.1016/j.forpol.2018.01.008

García-López, G.A., 2019. Rethinking elite persistence in neoliberalism: Foresters and technobureaucratic logics in Mexico's community forestry. World Dev. 120, 169-181. https://doi.org/10.1016/j.worlddev.2018.03.018

Gobeze, T., Bekele, M., Lemenih, M., Kassa, H., 2009. Participatory forest management and its impacts on livelihoods and forest status: the case of Bonga forest in Ethiopia. Int. For. Rev. $11,346-357$.

Green, K.E., Lund, J.F., 2015. The politics of expertise in participatory forestry: a case from Tanzania. For. Policy Econ. 60, 27-34. https://doi.org/10.1016/j.forpol.2014.11.012

Gross-Camp, N., Rodriguez, I., Martin, A., Inturias, M., Massao, G., 2019. The type of land we want: Exploring the limits of community forestry in Tanzania and Bolivia. Sustainability 11. https://doi.org/10.3390/su11061643

Haller, T., Galvin, M., Meroka, P., Alca, J., Alvarez, A., 2008. Who gains from community conservation?: Intended and unintended costs and benefits of participative approaches in Peru and Tanzania. J. Environ. Dev. 17, 118-144. https://doi.org/10.1177/1070496508316853

Hargreaves, J.R., Morison, L.A., Gear, J.S., Kim, J.C., Makhubele, M.B., Porter, J.D., Watts, C., Pronyk, P.M., 2007. Assessing household wealth in health studies in developing countries: a comparison of participatory wealth ranking and survey techniques from rural South Africa. Emerg. Themes Epidemiol. 4, 1-9. https://doi.org/10.1186/1742-7622-4-4

Jacob, T., Brockington, D., 2017. Learning from the other: Benefit sharing lessons for REDD+ implementation based on CBFM experience in Northern Tanzania. Land use policy. https://doi.org/10.1016/j.landusepol.2017.10.028 
Kabir, K.H., Knierim, A., Chowdhury, A., Herrera, B., 2019. Developing capacity of forest users through participatory forest management: Evidence from Madhupur Sal forest in Bangladesh. J. Sustain. For. 38, 149-170. https://doi.org/10.1080/10549811.2018.1540991

Kamoto, J., 2007. Improving forest beekeeping through monitoring in Chimaliro, Malawi, in: Guijt, I. (Ed.), Negotiated Learning: Collaborative Monitoring in Forest Resource Management. Resources for the Future, Washington (DC), pp. 104-113.

Kamoto, J., Clarkson, G., Dorward, P., Shepherd, D., 2013. Doing more harm than good? Community based natural resource management and the neglect of local institutions in policy development. Land use policy 35, 293-301. https://doi.org/10.1016/j.landusepol.2013.06.002

Kellert, S.R., Mehta, J.N., Ebbin, S.A., Lichtenfeld, L.L., 2000. Community natural resource management: Promise, rhetoric, and reality. Soc. Nat. Resour. 13, 705-715. https://doi.org/10.1080/089419200750035575

Kumar, K., Singh, N.M., Kerr, J.M., 2015. Decentralisation and democratic forest reforms in India: Moving to a rights-based approach. For. Policy Econ. 51, 1-8. https://doi.org/10.1016/J.FORPOL.2014.09.018

Kumar, S., 2002. Does Participation" in Common Pool Resource Management Help the Poor? A Social Cost-Benefit Analysis of Joint Forest Management in Jharkhand, India. World Dev. $30,763-782$.

Lambrick, F.H., Brown, N.D., Lawrence, A., Bebber, D.P., 2014. Effectiveness of Community Forestry in Prey Long Forest, Cambodia. Conserv. Biol. 28, 372-381.

LAMP, 2005. Building a future with our forests: Experiences of community- based forestry. LAMP booklet, SIDA.

Larson, A.M., 2002. Natural resources and decentralization in Nicaragua: Are local governments up to the job? World Dev. 30, 17-31. https://doi.org/10.1016/S0305-750X(01)00098-5

Lissu, U.A and von Mitzlaff, I., 2007. Moving towards sustainable harvesting of village Forests experience from Kiteto SULEDO forest. Arc Newsletter, Biannu. 25.

Liu, J., Innes, J.L., 2015. Participatory Forest Management in China: key challenges and ways forward. Int. For. Rev. 17, 477-484. https://doi.org/10.1505/146554815817476512 
Liu, Z., Rommel, J., Feng, S., 2018. Does It Pay to Participate in Decision-making? Survey Evidence on Land Co-management in Jiangsu Province, China. Ecol. Econ. 143, 199-209. https://doi.org/10.1016/j.ecolecon.2017.07.023

Luintel, H., Bluffstone, R.A., Scheller, R.M., Adhikari, B., 2017. The Effect of the Nepal Community Forestry Program on Equity in Benefit Sharing. J. Environ. Dev. 26, 297-321. https://doi.org/10.1177/1070496517707305

Lund, J.F., Rutt, R.L., Ribot, J., 2018. Trends in research on forestry decentralization policies. Curr. Opin. Environ. Sustain. https://doi.org/10.1016/j.cosust.2018.02.003

Lund, J.F., Saito-Jensen, M., 2013. Revisiting the Issue of Elite Capture of Participatory Initiatives. World Dev. 46, 104-112. https://doi.org/10.1016/j.worlddev.2013.01.028

Lund, J.F., Treue, T., 2008. Are We Getting There? Evidence of Decentralized Forest Management from the Tanzanian Miombo Woodlands. World Dev. 36, 2780-2800. https://doi.org/10.1016/j.worlddev.2008.01.014

Malimbwi, R., 2000. Natural Forest Management in Laiseri Village, A Pilot project for the land use management programme in Kiteto District. Tanzania.

Maraseni, T.N., Bhattarai, N., Karky, B.S., Cadman, T., Timalsina, N., Bhandari, T.S., Apan, A., Ma, H.O., Rawat, R.S., Verma, N., San, S.M., Oo, T.N., Dorji, K., Dhungana, S., Poudel, M., 2019. An assessment of governance quality for community-based forest management systems in Asia: Prioritisation of governance indicators at various scales. Land use policy 81, 750-761. https://doi.org/10.1016/j.landusepol.2018.11.044

Mitchell, K., Branigan, P., 2000. Using focus groups to evaluate health promotion interventions. Heal. Educ. Libr. Rev. J. Mark. Pract. Appl. Mark. Sci. Iss 100, 261-268.

Mogoi, J., Obonyo, E., Ongugo, P., Oeba, V., Mwangi, E., 2012. Communities, Property Rights and Forest Decentralisation in Kenya: Early Lessons from Participatory Forestry Management. Conserv. Soc. 10, 182-194. https://doi.org/10.4103/0972-4923.97490

Mohammed, A.J., Inoue, M., 2012. Drawbacks of decentralized natural resource management: experience from Chilimo Participatory Forest Management project, Ethiopia. J Res 17, 30 36. https://doi.org/10.1007/s10310-011-0270-9

Mohammed, A.J., Inoue, M., Shivakoti, G., 2017. Moving forward in collaborative forest management: Role of external actors for sustainable Forest socio-ecological systems. For. Policy Econ. 74, 13-19. https://doi.org/10.1016/j.forpol.2016.10.010 
Mollick, S.A., Rahman, K. M., Khan, I. N., Sadath, N. M., 2018. Evaluation of good governance in a participatory forestry program: A case study in Madhupur Sal forests of Bangladesh. For. Policy Econ. 95, 123-137. https://doi.org/10.1016/j.forpol.2018.07.014

Mustalahti, I., Lund, J.F., 2009. Where and How Can Participatory Forest Management Succeed? Learning From Tanzania, Mozambique, and Laos. Soc. Nat. Resour. 23, 31-44. https://doi.org/10.1080/08941920802213433

Mutune, J.M., Hansen, C.P., Wahome, R.G., Mungai, D.N., 2017. What rights and benefits? The implementation of participatory forest management in Kenya: The case of Eastern Mau Forest Reserve. J. Sustain. For. 36, 230-249. https://doi.org/10.1080/10549811.2017.1289105

Mutune, J.M., Lund, J.F., 2016. Unpacking the impacts of "participatory" forestry policies: Evidence from Kenya. For. Policy Econ. 69, 45-52. https://doi.org/10.1016/j.forpol.2016.03.004

Nielsen, M.R., Meilby, H., 2013. Determinants of Compliance with Hunting Regulations Under Joint Forest Management in Tanzania. South African J. Wildl. Res. 43, 120-137. https://doi.org/10.3957/056.043.0210

Olken, B.A., 2007. Monitoring Corruption: Evidence from a Field Experiment in Indonesia. J. Polit. Econ. 115, 200-249.

ORGUT, 2010. Securing Sustainability of LAMP Initiatives Support to SULEDO Forest Reserve, Consultancy Inputs on Harvest Operation and Forest Management.

Pasgaard, M., Chea, L., 2013. Double inequity? The social dimensions of deforestation and forest protection in local communities in northern Cambodia. Österreichische Zeitschrift für Südostasienwissenschaften, 2, 285-269. https://doi.org/10.4232/10.ASEAS-6.2-6

Persha, L., Andersson, K., 2014. Elite capture risk and mitigation in decentralized forest governance regimes. Glob. Environ. Chang. 24, 265-276. https://doi.org/10.1016/j.gloenvcha.2013.12.005

Persha, L., Blomley, T., 2009. Management decentralization and montane forest conditions in Tanzania. Conserv. Biol. 23, 1485-1496.

Persson, J., Prowse, M., 2017. Collective action on forest governance: An institutional analysis of the Cambodian community forest system. For. Policy Econ. 83, 70-79. https://doi.org/10.1016/j.forpol.2017.06.008 
R Core Team (2018) R: A Language and Environment for Statistical Computing. R Foundation for Statistical Computing, Vienna.

Rai, R.K., Dhakal, A., Khadayat, M.S., Ranabhat, S., 2017. Is collaborative forest management in Nepal able to provide benefits to distantly located users? For. Policy Econ. 83, 156-161. https://doi.org/10.1016/j.forpol.2017.08.004

Reinikka, R., Svensson, J., 2004. Local Capture: Evidence From a Central Government Transfer Program in Uganda*. Q. J. Econ. 679-705.

Ribot, J., 2004. Waiting for Democracy, The Politics of Choice in Natural Resource Decentralization, Foreign Policy. United States of America. https://doi.org/10.2307/1148781

Ribot, J.C., Lund, J.F., Treue, T., 2010. Democratic decentralization in sub-Saharan Africa: its contribution to forest management, livelihoods, and enfranchisement. Environ. Conserv. 37, $35-44$.

Saito-Jensen, M Nathan, I Treue, T., 2010. Beyond elite capture? Community-based natural resource management and power in Mohammed Nagar village, Andhra Pradesh, India. Environ. Conserv. 37, 327-335. https://doi.org/10.1017/S0376892910000664

Scheba, A., Mustalahti, I., 2015. Rethinking “expert” knowledge in community forest management in Tanzania. For. Policy Econ. 60, 7-18. https://doi.org/10.1016/j.forpol.2014.12.007

Schreckenberg, K., Luttrell, C., 2009. Participatory Forest Management: A Route to Poverty Reduction? Int. For. Rev. 11, 221-238. https://doi.org/10.1505/ifor.11.2.221

Schusser, C., Krott, M., Yufanyi Movuh, M.C., Logmani, J., Devkota, R.R., Maryudi, A., Salla, M., Bach, N.D., 2015. Powerful stakeholders as drivers of community forestry - Results of an international study. For. Policy Econ. 58, 92-101. https://doi.org/10.1016/j.forpol.2015.05.011

Senganimalunje, T.C., Chirwa, P.W., Babalola, F.D., 2015. Potential of Institutional Arrangements for Sustainable Management of Forests Under Co-Management with Local Forest Organisations in Mua-Livulezi Forest Reserve, Mtakataka, Malawi. Source Int. For. Rev. 17, 340-354. https://doi.org/10.1505/146554815815982602

Sungusia, E., Lund, J.F., 2016. Against all policies: Landscape level forest restoration in Tanzania. World Dev. Perspect. 3, 35-37. https://doi.org/10.1016/j.wdp.2016.11.012 
Tole, L., 2010. Reforms from the Ground Up: A Review of Community-Based Forest

Management in Tropical Developing Countries. Environ. Manage. 45, 1312-1331. https://doi.org/10.1007/s00267-010-9489-z

UNDP, 2012. Suledo Forest Community, Tanzania. Equator Initiative Case Study Series. Local sustainable development solutions for people, nature and resilient communities. New York, NY.

URT, 2012. Participatory Forest Management in Tanzania Facts and Figures. Ministry of Natural Resources and Tourism. Forestry and Beekeeping Division. Government Printer. Dar es Salaam. Tanzania.

URT, 2011. SULEDO Village Land Forest Reserve management and sustainable harvesting plan. Ministry of Natural Resources and Tourism. Forestry and Beekeeping Division. Dar es Salaam. Tanzania.

URT, 2007. Community Based Forest Management guidelines. Ministry of Natural Resources and Tourism. Forestry and Beekeeping Division. Government Printer. Dar es Salaam. Tanzania.

URT, 2006. Participatory Forest Management in Tanzania Facts and Figures. Ministry of Natural Resources and Tourism. Forestry and Beekeeping Division. Government Printer. Dar es Salaam. Tanzania.

URT, 2002. Forest Act of Tanzania. no.14 of 7th June 2002. Ministry of Natural Resources and Tourism. Forestry and Beekeeping Division. Government Printer. Dar es Salaam. Tanzania.

URT, 1998. National Forest Policy of Tanzania. Ministry of Natural Resources and Tourism. Forestry and Beekeeping Division. Government Printer. Dar es Salaam. Tanzania.

URT, 1982. The Local Government (District Authorities) Act, Local Government Areas, Establishment, Registration and Variation of area of Local Government Authorities. Government Printer. Dar es Salaam. Tanzania.

Vyamana, V., 2009. Participatory forest management in the Eastern Arc Mountains of Tanzania: who benefits? Int. For. Rev. 11, 239-253. https://doi.org/10.1505/ifor.11.2.239

Zulu, L.C., 2008. Community forest management in southern Malawi: solution or part of the problem? Soc. Nat. Resour. 21, 687-703. 